\title{
In vitro evaluation of bio agents against rice sheath blight pathogen Rhizoctonia solani Kuhn
}

Shrishti Lingwal* and Vishwanath ${ }^{1}$

Department of Mycology and Plant Pathology, Institute of Agricultural Sciences, Banaras Hindu University, Varanasi (U.P.) India

${ }^{1}$ Department of Plant Pathology, G. B. Pant University of Agriculture and Technology, Pantnagar (Uttarakhand) India

\section{ARITCLE INFO}

Received : 05.07 .2018

Revised : 05.09 .2018

Accepted : 20.09 .2018

\section{KEY WORDS :}

Biological control, Pseudomonas florescens, Rhizoctonia solani, Sheath blight of rice, Trichoderma harzianum
*Corresponding author:

1.shrish.10@gmail.com

\begin{abstract}
It is now an established fact that strains of Trichoderma and Pseudomonas are most capable among all the potent biological control agents against phytopathogenic microorganisms recorded till now. They are effective against pathogenic microbes by the virtue of their capacity to produce some antagonistic chemicals (antibiosis), competition for food and nutrition, direct killing (parasitisation) etc. One such study was conducted to know the interaction between Trichoderma spp. against Rhizoctonia solani causing sheath blight disease in rice. Nine isolates of Trichoderma were tested for its parasitisation ability under dual culture shown and it was found that $77.03-100$ per cent inhibition of Rhizoctonia after 72 hours of inoculation. Also, the effect of inhibiting volatiles was seen by inverted plate technique. It was found that none of the nine isolate of Trichoderma significantly reduced the growth of $R$. solani by producing volatiles and inhibition percent was found only $3.88-5.60$ per cent. Three isolates of Pseudomonas florescens inhibited the growth of the test fungus by only 30.36-34.81per cent, which is very less when compared to fungal biocontrol agent Trichoderma.
\end{abstract}

How to view point the article : Lingwal, Shrishti and Vishwanath (2018). In vitro evaluation of bio agents against rice sheath blight pathogen Rhizoctonia solani Kuhn. Internat. J. Plant Protec., 11(2) : 146-150, DOI : 10.15740/HAS/IJPP/11.2/146-150, Copyright@ 2018: Hind Agri-Horticultural Society. 